\title{
PENGEMBANGAN MEDIA PEMBELAJARAN KOTAK POP UP UNTUK MENINGKATKAN MOTIVASI BELAJAR SISWA MATERI CAHAYA DAN ALAT OPTIK KELAS VIII SMPN 19 MATARAM
}

\author{
Nurlaelah $^{1^{*}}$, Johri Sabaryati ${ }^{2}$, Zulkarnain $^{3}$ \\ ${ }^{1 *}$ Mahasiswa Sarjana Program Studi Pendidikan Fisika Universitas Muhammadiyah Mataram \\ ${ }^{283}$ Dosen Progran Studi Pendidikan Fisika Universitas Muhammadiyah Mataram \\ *Corresponding author : \\ Email: joyafarashy@gmail.com
}

Diterima 9 Mei 2019, Disetujui 15 Mei 2019

\begin{abstract}
ABSTRAK
Tujuan dari penelitian ini untuk mengembangkan media pembelajaran kotak pop up pada pokok bahasan cahaya dan alat optik, untuk meningkatkan motivasi belajar siswa. Penelitian ini menggunakan metode research and development (R \& D). Sebagai subjek dalam penelitian ini adalah siswa SMPN 19 Mataram Kelas VIII ${ }^{\mathrm{C}}$ sebanyak 35 siswa. Data diperoleh melalui wawancara, angket dan dokumentasi. Teknik analisis data yang digunakan adalah deskriptif kualitatif untuk mengukur motivasi belajar siswa. Hasil penelitian menunjukkan bahwa media pembelajaran yang dikembangkan berupa kotak Pop Up memiliki kriteria yang sangat baik berdasarkan penilaian dari ahli dan praktisi. Media kotak pop up yang dikembangkan juga memiliki kriteria yang cukup baik untuk meningkatkan motivasi belajar siswa dengan persentase sebesar $75 \%$ bila dibandingkan sebelum menggunakan kotak Pop Up yaitu sebesar $49 \%$. Peningkatan motivasi belajar secara klasikal juga berada pada kriteria sedang dengan normalisasi gain sebesar 0,50 . Berdasarkan hasil dari penelitian ini dapat disimpulkan bahwa media pembelajaran kotak pop up dapat meningkatkan motivasi belajar siswa kelas VIIIC SMPN 19 Mataram Tahun Pelajaran 2017/2018.
\end{abstract}

Kata kunci : Pengembangan, Media Pembelajaran, Kotak Pop-Up,Motivasi belajar.

\section{PENDAHULUAN}

Pembelajaran pada hakekatnya adalah proses komunikasi, yaitu proses penyampaian pesan dari guru melalui saluran atau media tertentu ke penerima pesan. Pesan yang akan dikomunikasikan adalah materi ataupun konsepkonsep yang ada dalam kurikulum. Keberhasilan dalam proses mengajar yang disampaikan oleh seorang guru dalam belajar di kelas dipengaruhi oleh banyak faktor antara lain guru, peserta didik, lingkungan belajar, kurikulum, sumber belajar dan lain-lain. Guru dan peserta didik merupakan faktor yang paling penting dalam proses pembelajaran. Kegiatan pembelajaran merupakan suatu proses yang tidak lepas dari komponen-komponen lain yang saling yang saling berinteraksi didalamnya. Salah satu komponen tersebut adalah media pembelajaran.

Penggunaan media pembelajaran yang merupakan alat bantu yang dipergunakan guru untuk menyampaikan materi pelajaran kepada peserta didik.Guru dapat menciptakan dan mengembangkan suatu media pembelajaran untuk peserta didik,penggunaan media pembelajaran akan berpengaruh terhadap kegiatan peserta didik selama proses belajar mengajar.Seorang guru harus mampu memiliki media pembelajaran yang tepat agar peserta didik dapat termotivasi untuk berperan aktif dalam pembelajaran.

Motivasi belajar peserta didik dalam pembelajaran fisika masih sangat rendah sehingga mengakibatkan prestasi belajar menurun. Memberikan motivasi kepada peserta didik berarti menggerakkan peserta didik untuk melakukan sesuatu atauingin melekukan sesuatu, oleh karena itu pentingnya menciptakan kondisi tertentu agar peserta didik termotivasi dan ingin terus belajar. Seorang guru yang kreatif harus dapat meningkatkan motivasi belajar peserta didik dalam pembelajaran fisika dengan menciptakan suatu media pembelajaran yang dapat membantu peserta didik agar lebih termotivasi dalam pelajaran fisika.

Masalah yang sering terjadi disekolah yaitu metode pengajaran yang digunakan oleh guru yang bertindak sebagai sumber utama dan peserta didik adalah pendengar dalam proses pembelajaran serta kurang maksimalnya 
penggunaan media dan teknologi dalam proses pembelajaran. Pada umumnya penggunaan media pembelajaran sangat membantu guru mengembangkan dan memperdalam proses belajar mengajar di kelas. Penggunaan media pembelajaran yang bervariasi dengan tepat dapat mempengaruhi aktivitas, minat dan motivasi belajar peserta didik yang tentunya akan mempengaruhi prestasi belajarnya.

Dari penelitian yang telah dilakukan oleh Mahayani (2017)" Pengembangan media pembelajaran berupa kotak pop up untuk menunjang pembelajaran fisika materi cahaya dan alat optik"diketahui bahwa kotak pop up yang di kembangkan masih berupa kertas putih polos pada tulisan materi hasil penelitian ini untuk medianya dikatakan sangat layak dengan $89,77 \%$ dan $91,11 \%$ adalah ketertarikkan peserta didik dalam menggunakan media kotak pop up.

Berdasarkan uraian diatas,maka peneliti tertarik untuk mengembangkan media pembelajaran dengan judul "Pengembangan Media Pembelajaran Kotak Pop Up Untuk Menunjang Motivasi Belajar Siswa Materi Cahaya dan Alat Optik"

\section{METODE PENGEMBANGAN Model Pengembangan}

Jenis penelitian ini adalah penelitian pengembangan $\mathrm{R}$ \& $\mathrm{D}($ Reseach and Development). Reseach \& Development adalah metode penelitian yang digunakan untuk menghasilkan produk (Sugiyono, 2013). Produk yang dihasilkan dalam penelitian pengembangan ini adalah media pembelajaran kotak pop-up.

Penelitian dan pengembangan adalah suatu proses atau langkah-langkah untuk mengembangkan suatu produk baru atau menyempurnakan produk yang telah ada yang dapat dipertanggung jawabkan. Produk tersebut tidak selalu berbentuk benda atau perangkat keras seperti buku, modul, alat bantu pembelajaran di kelas atau di laboratorium, tetapi bisa juga perangkat lunak seperti program komputer untuk pengolahan data, pembelajaran di kelas, perpustakaan atau laboratorium, ataupun modelmodel pendidikan, pembelajaran, pelatihan, bimbingan, evaluasi, dan manajemen. Pada dasarnya penelitian dan pengembangan mempunyai dua tujuan utama, yaitu: (1) mengembangkan produk dan (2) menguji keefektifan produk dalam mencapai tujuan. Tujuan pertama disebut sebagai fungsi pengembangan sedangkan tujuan kedua disebut sebagai fungsi validasi. Produk dari model penelitian ini diharapkan dapat meningkatkan mutu pendidikan dan pembelajaran.

Teknik pengumpulan data pada penelitian ini adalah angket dan dokumentasi. Angket digunakan untuk mengumpulkan data tentang kelayakan media pembelajaran yang dibuat dan akan dijawab oleh responden yang terkait pembelajaran antara lain: ahi materi, ahli media,guru dan siswa sebagai pengguna. Desain penelitian ini menggunakan satu kelas sampel sebagai kelas uji coba (One Group Pre- Test and Post-test Design). (Sabaryati,2016)

\section{Prosedur Pemgembangan}

\section{Lokasi Penelitian}

Penelitian ini akan dilaksanakan di SMPN 19 Mataram melibatkan siswa kelas VIII pada bulan Mei tahun 2018.

\section{Waktu Penelitian}

Penelitian ini telah dilaksanakan pada bulan Mei sampai Juni 2018 pada Siswa SMPN 19 Mataram Kelas VIII .

\section{Langkah-Langkah Penelitian}

Langkah-langkah penelitian dan pengembangan Kotak pop-up sebagai berikut:

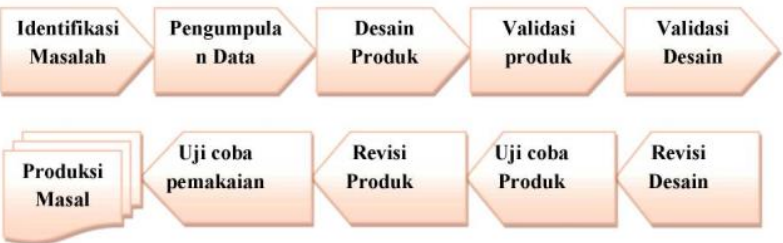

Gambar Langkah-Langkah Penelitian Pengembangan (Sabaryati,2016)

Penelitian ini dilakukan sampai pada tahap uji coba produk karena keterbatasan waktu dan dana. Media dikatakan valid apabila telah divalidasi oleh ahli dan diuji keefektifannya serta keefisiennya oleh peneliti.

\section{Metode penelitian Tahap I}

\section{Potensi Dan Masalah}

Penelitian dapat berangkat dari potensi dan masalah yang ada. Potensi adalah sesuatu yang bila didayagunakan akan memiliki nilai tambah (Sugiyono, 2016). Potensi yang ditemukan dalam penelitian ini adalah buku dalam kegiatan pembelajaran. Masalah dalam penelitian ini adalah kurangnya motivasi belajar siswa kelas VIII terhadap mata pelajaran FISIKA.

\section{Pengumpulan Data}

Langkah yang diambil setelah ditemukan potensi dan masalah dalam penelitian ini adalah mengumpulkan informasi.Informasi dapat dilakukan sebagai bahan untuk perencanaan produk tertentu. Pada penelitian ini, peneliti akan menghasilkan dan mengembangkan produk berupa Kotak pop-up. Berdasarkan hasil pengumpulan informasi yang telah dilakukan disekolah, ditemukan permasalahan adalah belum adanya respon siswa terhadap media pembelajaran yang lain selain buku.Pemicu salah satunya adalah kurangnya media pembelajaran 
yaitu buku penunjang siswa. Oleh karena itu, peneliti akan mengembangkan media pembelajaran berupa Kotak pop-up yang menarik dan sangat praktis di gunakan dalam pembelajaran.

\section{Desain Produk}

Dalam hal ini peneliti mulai membuat media pembelajaran yaitu kotak Pop-up. Pada tahap ini peneliti mempelajari cara pembuatan dan penggunaan kotak Pop-up. Kemudia menyiapkan materi fisika pada media pembelajaran berupa kotak Pop-up. Pengembangan media Kotak pop-up dilakukan dengan uji coba produk pengembangan menggunakan desain validasi logis dengan tipe validasi isi (content validity).Validasi ini dilakukan para ahli bidang studi. Ahli pengukuran dan para ahli yang memiliki keahlian yang relevan dengan bidang kajiannya.

Kegiatan validasi isi ini akan dilakukan oleh ahli media pembelajaran dan bahan ajar fisika denngan cara mengisi instrument berupa angket dan memberi kritik atau saran terhadap produk pengembangan. Validasi isi dilakukan agar mengetahui kelayakan isi produk yang dikembangkan.

Validasi ahli pada pengembangan media pembelajaran kotak pop-up dilakukan oleh tiga orang dosen dan satu orang guru. Kriteria dosen diantaranya minimal pendidikan S2 dan guru minimal menempuh pendidikan S1 dan berpengalaman mengajar materi Cahaya dan Alat-alat Optik .Ahli media yang telah menjadi validator produk pengembangan merupakan dosen yang menguasai bidang media pembelajaran yang telah berpengalaman dan telah menempuh pendidikan S2 dan guru minimal menempuh pendidikan S1.

Validasi Desain Produk

Validasi produk dapat dilakukan dengan cara menghadirkan beberapa pakar tenaga ahli yang sudah berpengalaman untuk menilai produk baru yang dirancang tersebut. Validasi isi dilakukan oleh para ahli bidang studi, ahli pengukuran, dan pakar yang memiliki keahlian yang relevan dengan bidang kajiannya.

Kegiatan validasi isi ini akan dilakukan oleh ahli media pembelajaran dan ahli materi Fisika dengan cara mengisi instrumen berupa angket dan memberi kritik atau saran terhadap produk pengembangan. Validasi isi dilakukan agar mengetahui kelayakan isi produk yang dikembangkan. Validasi ahli pada pengembangan Kotak pop-up merupakan tiga orang dosen dan satu orang guru Fisika. Kriteria dosen diantaranya minimal menempuh pendidikan S2 dan guru minimal menempuh pendidikan $\mathrm{S} 1$ dan berpengalaman mengajar materi Cahaya dan Alat-alat Optik.

\section{Perbaikan Desain Produk}

Semua kelengkapan dan peralatan media Kotak pop-up IPA Fisika didesain semenarik mungkin agar dapat menarik perhatian siswa dalam proses pembelajaran.

1. Kotak pop-up yang memiliki 2 materi cahaya dan edisi alat optik yang disesuaikan dengan besar kotak pop-upnya.

2. Kotak pop-up ukurannya kecil dan bisa disimpan didalam tas.

3. Susunan dari segi kotak pop-upnya yaitu materi singkat.

4. Susunan dari segi kotak pop-up memiliki evaluasi.

\section{Uji Coba Produk}

Subjek uji coba terdiri atas ahli bidang isi atau materi, ahli bidang perancangan produk dan sasaran pemakai produk. Dimana subjek uji coba untuk ahli materi dan perancangan atau media berfungsi sebagai validator yaitu dengan mengisi instrument berupa angket dan memberi kritik atau saran terhadap produk pengembangan. Validasi dilakukan agar mengetahui kelayakan isi produk yang dikembangkan.

\section{Jenis Data}

Jenis data dalam penelitian ini adalah data kualitatif dan data kuantitaif.Data kualitatif berupa komentar dari ahli materi, ahli media, praktisi lapangan, dan siswa terhadap media pembelajaran Kotak pop-up IPA Fisika.Sedangkan data kuantitatif didapatkan dari skor validasi dari ahli materi, ahli media, praktisi lapangan,, dan siswa,, dikonversi skor tersebut.

\section{Instrumen Pengumpulan Data}

Instrumen penelitian digunakan untuk mengukur nilai variabel yang akanditeliti (Sugiyono, 2017). Secara spesifikasi fenomena yang terjadi disebut variable penelitian.Instrumen yang digunakan dalam penelitian ini lembar angket motivasi (kuisioner). Kuisioner merupakan teknik pengumpulan data yang dilakukan dengan cara memberi seperangkat pertanyaan atau pernyataan tertulis kepada responden untuk menjawabnya (Sugiyono, 2017).

Berbagai skala sikap dapat dikumpulkan melalui angket.Pada penelitian ini skala sikap yang digunakan adalah skala likert. Jawaban dari setiap item instrument yang menggunakan skala likert mempunyai garaduasi dari sangat positif sampai sangat negatif

Produk.

Tabel 3.1 Tabel Angket Validasi

\begin{tabular}{|c|c|c|c|}
\hline $\begin{array}{l}\mathrm{N} \\
0\end{array}$ & Indikator & Item & $\begin{array}{l}\text { Nom } \\
\text { or }\end{array}$ \\
\hline 1. & $\begin{array}{l}\text { Kriteria } \\
\text { pendidik } \\
\text { an }\end{array}$ & $\begin{array}{l}\text { a. Mengetahui } \\
\text { cakupan media } \\
\text { Pembelajaran }\end{array}$ & \\
\hline
\end{tabular}




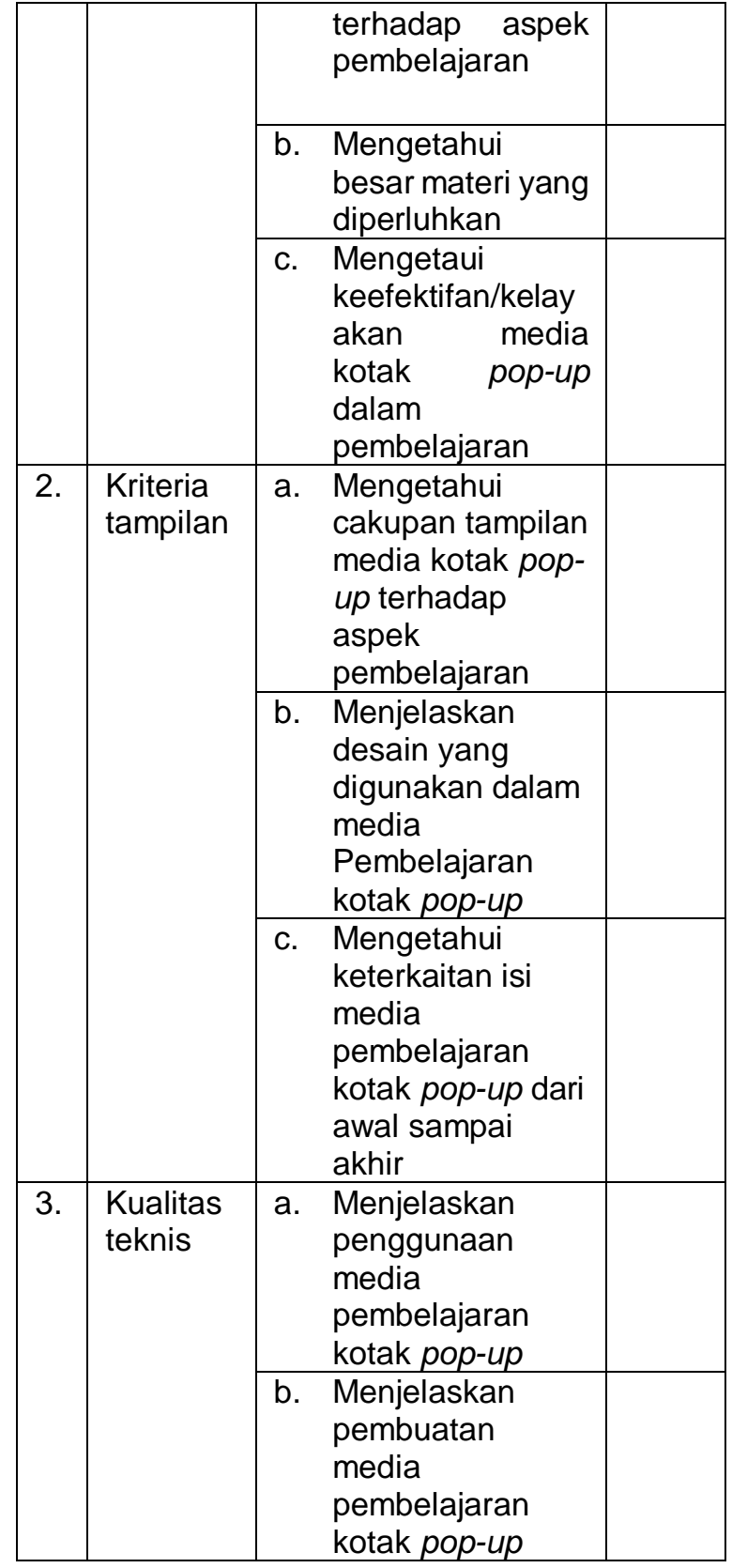

Skala pengukuran yang digunakan untuk mengukur validasi produk adalah skala likert yang memiliki gradulasi penilaian dari sangat positif sampai sangat negatif. Teknik skorsing dalam skala likert adalah sebagai berikut:

1. Sangat Setuju (Sangat Positif) diberi skor 5

2. Setuju (Positif) diberi skor 4

3. Kurang Setuju (Negatif) diberi skor 3

4. Tidak Setuju (Sangat Negatif) diberi skor 2

5. Sangat Tidak Setuju (Sangat Negatif) diberi skor 1 (Hake : 1998)

\section{Teknis Analisis Data}

Analisis data dilakukan setelah proses pengumpulan data, dimana penelitian ini lebih menitik bertakan pada pengembangan media pembelajaran Fisika Kotak pop-up pada pokok bahasan cahaya dan alat-alat optik. Angket yang digunakan harus dilakukan uji validasi dan uji releabilitas.Dimana teknik analisis data untuk percobaan ini adalah teknik angket dan wawancara. Angket diberikan kepada guru fisika dan siswa mengenai produk atau media yang akan dikembangkan. Dimana angket digunakan untuk menguji kelayakan media, sedangkan metode wawancara dilakukan pada beberapa tahap pengembangan yaitu analisis kebutuhan untuk pengembangan produk.

\section{Metode Penelitian Tahap II}

Model Rancangan Eksprimen Untuk Menguji

Uji coba produk merupakan bagian penting dalam penelitian pengembangan yang dilakukan setelah rancangan produk selesai.Uji coba produk dalam penelitian ini dilakukan untuk mengetahui apakah media pembelajaran fisika Kotak pop-up yang dikembangkan dapat menunjang belajar siswa atau tidak dapat menunjang belajar pada siswa.

Desain uji coba dilakukan dalam penelitian ini adalah dengan cara menerapkan media pembelajaran fisika Kotak pop-up dengan pengujian yang dilakukan dengan cara eksprimen yaitu untuk mengetahui peningkatkan motivasi belajar pada siswa dengan menggunakan media pembelajaran fisika Kotak pop-up. Desain penelitian yang digunakan adalah

$$
0_{1} X 0_{2}
$$

Gambar 3.2 Desain Penelitian (Pretest-

\section{Postest design)}

Keterangan :

$0_{1}=$ motivasi sebelum menerapkan media Kotak pop-up

$0_{2}=$ motivasi setelah menerapkan media Kotak pop-up

\section{Subjek Uji Coba}

Adapun subjek uji coba pada penelitian ini adalah peserta didik kelas VIII SMPN 19 Mataram. Teknik Pengumpulan Data

Teknik pengumpulan data motivasi belajar siswa adalah menggunakan angket motivasi belajar yng diberikan sebelum menggunakan media pembelajaran fisika Kotak pop-up dan setelah menggunakan media pembelajaran fisika Kotak pop-up.Angket motivasi terdiri dari pernyataan positif dan pernyataan negative.Skorskor motivasi belajar dapat dilihat pada tabel berikut.

Tabel 3.3 Skor-Skor Skala Sikap

\begin{tabular}{|l|l|l|l|l|}
\hline \multirow{2}{*}{ No } & \multicolumn{2}{|l|}{ Pernyataan positif } & \multicolumn{2}{|c|}{$\begin{array}{c}\text { Pernyataan } \\
\text { negative }\end{array}$} \\
\cline { 2 - 5 } & Skala sikap & & $\begin{array}{c}\text { Skala } \\
\text { sikap }\end{array}$ & Skor \\
\hline 1. & $\begin{array}{l}\text { Sangat } \\
\text { setuju }\end{array}$ & 5 & $\begin{array}{l}\text { Sangat } \\
\text { setuju }\end{array}$ & 1 \\
\hline 2. & Setuju & 4 & Setuju & 2 \\
\hline
\end{tabular}




\begin{tabular}{|l|l|l|l|l|}
\hline 3. & $\begin{array}{l}\text { Kurang } \\
\text { setuju }\end{array}$ & 3 & $\begin{array}{l}\text { Kurang } \\
\text { setuju }\end{array}$ & 3 \\
\hline 4. & Tidak setuju & 2 & $\begin{array}{l}\text { Tidak } \\
\text { setuju }\end{array}$ & 4 \\
\hline 5. & $\begin{array}{l}\text { Sangat } \\
\text { tidak setuju }\end{array}$ & 1 & $\begin{array}{l}\text { Sangat } \\
\text { tidak } \\
\text { setuju }\end{array}$ & 5 \\
\hline
\end{tabular}

Angket motivasi belajar digunakan untuk mengetahui apakah penggunaan media pembelajaran fisika Kotak pop-up terhadap motivasi belajar siswa. Pada tabel 3.3 merupakan angket motivasi belajar diberikan kepada siswa yang disusun berdasarkan kis-kisi sebagai berikut:

Tabel 3.4 Kisi-Kisi Motivasi

Belajar Siswa

\begin{tabular}{|c|c|c|c|}
\hline $\begin{array}{l}\mathrm{N} \\
\mathrm{O}\end{array}$ & Indikator & Item & $\begin{array}{c}\text { Nomo } \\
r\end{array}$ \\
\hline \multirow[t]{2}{*}{1.} & \multirow[t]{2}{*}{ Perhatian } & $\begin{array}{l}\text { Siswa } \\
\text { mendengarkan } \\
\text { arahan guru }\end{array}$ & \\
\hline & & $\begin{array}{l}\text { Siswa ingin } \\
\text { tahu materi } \\
\text { pelajaran dan } \\
\text { memperhatika } \\
\text { n pelajaran }\end{array}$ & \\
\hline \multirow[t]{2}{*}{2.} & \multirow[t]{2}{*}{ Relevansi } & $\begin{array}{l}\text { Siswa } \\
\text { memperhatika } \\
\text { n kesesuaian } \\
\text { materi yang } \\
\text { terdapat pada } \\
\text { Kotak pop-up } \\
\text { dengan yang } \\
\text { guru jelaskan }\end{array}$ & \\
\hline & & $\begin{array}{l}\text { Siswa } \\
\text { mengetahui } \\
\text { hubungan } \\
\text { materi } \\
\text { pelajaran } \\
\text { dengan } \\
\text { kehidupan } \\
\text { sehari-hari }\end{array}$ & \\
\hline \multirow[t]{2}{*}{3.} & \multirow[t]{2}{*}{$\begin{array}{c}\text { Kepercayaaa } \\
\text { n diri }\end{array}$} & $\begin{array}{l}\text { Siswa mampu } \\
\text { menjawab } \\
\text { pertanyaan } \\
\text { yang diberikan } \\
\text { oleh guru } \\
\text { waktu } \\
\text { menggunakan } \\
\text { Kotak pop-up }\end{array}$ & \\
\hline & & $\begin{array}{l}\text { Siswa aktif } \\
\text { dalam diskusi } \\
\text { kelompok }\end{array}$ & \\
\hline 4. & Kepuasan & $\begin{array}{l}\text { Siswa puas } \\
\text { dengan media } \\
\text { pembelajaran } \\
\text { Kotak pop-up }\end{array}$ & \\
\hline
\end{tabular}

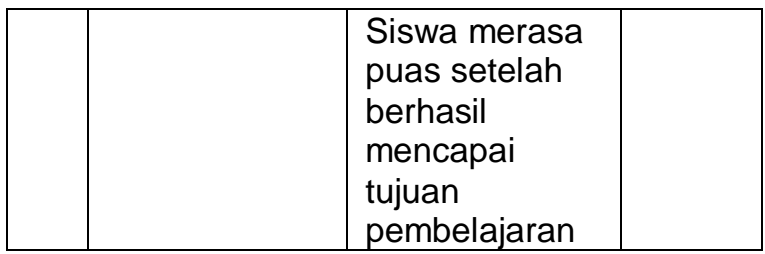

\section{Teknik Analisis Data}

Teknik Analisis Data Angket Validasi Produk

Teknis analisis data pada penelitian ini bertujuan untuk mendapatlan perangkat pembelajaran yang berkualitas. Adapun langkahlangkah yang digunakan dalam memenuhi kriteria kualitas produk yang dikembangkan adalah sebagai berikut:

1. Data berupa skor ahli/praktisi yang diperoleh melalui lembar validasi yang dijumlahkan

2. Total skor aktual yang diperoleh kemudian dikonvrsikan menjadi data kualitatif skala lima seperti pada tabel 3.4 berikut:

Tabel 3.4 Konversi Data Kuantitatif ke Kualitatif Dengan Skala Lima

\begin{tabular}{|c|c|c|}
\hline $\begin{array}{c}\text { Interval } \\
(\mathrm{M}+1,50 \mathrm{~s})<\mathrm{X}\end{array}$ & $\begin{array}{l}\text { Kriteria } \\
\text { Sangat }\end{array}$ & $\begin{array}{c}\text { Skor } \\
\text { A }\end{array}$ \\
\hline $\begin{array}{c}(\mathrm{M}+0,50 \mathrm{~s})<\mathrm{X} \leq \\
(\mathrm{M}+1,50 \mathrm{~s})\end{array}$ & $\begin{array}{l}\text { balk } \\
\text { Baik }\end{array}$ & B \\
\hline $\begin{array}{c}(M-0,50 s)<X \leq \\
(M+0,50 s)\end{array}$ & $\begin{array}{l}\text { Cukup } \\
\text { baik }\end{array}$ & C \\
\hline $\begin{array}{c}(\mathrm{M}-1,50 \mathrm{~s})<\mathrm{X} \leq \\
(\mathrm{M}-0,50 \mathrm{~s})\end{array}$ & $\begin{array}{l}\text { Kurang } \\
\text { baik }\end{array}$ & D \\
\hline $\mathrm{X} \leq(\mathrm{M}-1,50 \mathrm{~s})$ & Tidak baik & $E$ \\
\hline
\end{tabular}

(Azwar, 2015)

Keterangan:

$\mathrm{X}=$ Total skor responden

$M=$ Mean ideal, $1 / 2$ (skor maksimal ideal+skor minimal ideal)

$s$ = Simpangan baku ideal, 1/6 (skor maksimal ideal-skor minimal ideal)

skor maksimal ideal $=\sum$ butir criteria $\mathrm{x}$ skor tinggi

skor minimal ideal $=\sum$ butir criteria $\mathrm{x}$ skor terendah Berdasarkan kriteria yang terdapat pada

tabel 3.4 kemudian dibuat criteria validitas perangkat pembelajaran yang dikembangkan.Komponen perangkat pembelajaran yang dikembangkan memiliki jumlah butir pada lembar validasi untuk angket penilaian berbeda-beda, maka kriteria kevalidannya juga berbeda. Hasil validasi oleh ahli kemudian dikonversikan menjadi skala lima. Perangkat pembelajaran yang dikembangkan dikatakan valid, jika minimal tingkat validitas yang dicapai kategori baik.

Teknik Analisis Data Angket Motivasi

Analisis data dilakukan setelah proses pengumpulan data, dimana penelitian ini lebih menitik beratkan pada pengembangan Kotak pop- 
up untuk meningkatkan motivasi belajar siswa kelas VII materi cahaya dan alat optik.. Angket yang digunakan harus dilakukan uji validasi dan uji releabilitas.Dimana teknik analisis data untuk percobaan ini adalah teknik angket dan dokumentasi.

\section{Uji Validitas}

Untuk menghitung banyaknya pernyataan yang valid atau tidaknya dapat dihitung nilai validitas dengan rumus Pearson Product Moment adalah:

$$
r_{x y}=\frac{n \sum X_{i} Y_{i}-\left(\sum X_{i}\right) \cdot\left(\sum Y_{i}\right)}{\sqrt{\left\{n \sum X_{i}^{2}-\left(\sum X_{i}\right)^{2}\right\} \cdot\left\{n \cdot \sum Y_{i}^{2}-\left(\sum Y_{i}\right)^{2}\right\}}}
$$

Keterangan:

$r_{x y}=$ koefisien korelasi product moment

$\Sigma \mathrm{X}=$ jumlah skor butir soal

$\sum \mathrm{Y}=$ Jumlah skor total

$\hat{N}$ = Jumlah responden

$\sum \mathrm{X}^{2}=$ Jumlah kuadrat skor butir soal

$\sum \mathrm{Y}^{2}=$ Jumlah kuadrat skor total soal

$\sum X Y=$ Jumlah hasil kali skor butir soal

\section{Uji Reliabilitas}

(Riduwan, 2014)

Uji reliabilitas dilakukan untuk mengetahui reliabilitas angket, (instrumen) yang digunakan. Langkah-langkah mencari nilai reliabilitas sebagai berikut:

$$
r_{11}=\left(\frac{k}{k-1}\right)\left(1-\frac{\sum S_{i}}{S_{t}}\right)
$$

Keterangan:

$r_{11}=$ Nilai reliabilitas

$\sum S_{i}=$ Jumlah varians skor tiap-tiap item

$S_{t}=$ Varians total

$k=$ Jumlah item

Selain itu perlu dicari nilai varians untuk menentukan reliabilitas angket motivasi belajar siswa menggunakan rumus sebagai berikut:

$S_{i}=\frac{\sum X_{i}^{2}-\frac{\left(\sum X_{i}\right)^{2}}{N}}{N}$

Keterangan:

$S_{i} \quad=$ Varians skor tiap-tiap item

$\sum X_{i}{ }^{2}=$ Jumlah kuadrat item $\mathrm{Xi}$

$\left(\sum X_{i}\right)^{2}=$ Jumlah item Xi dikuadratkan

$\mathrm{N} \quad=$ Jumlah responden

Nilai korelasi yang diperoleh dikonsultasikan ke tabel Product Moment dengan taraf $\alpha=0,05$ atau $\alpha=0,01$. Jika harga $r_{\text {hitung }}>r_{\text {tabel }}$

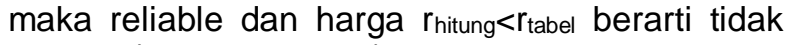
reliable (Riduwan, 2014).

Motivasi Belajar Siswa

Untuk enghitung angket tingkat motivasi siswa digunkan

Tabel 3.4 Penilaian Skala $1-5$

Motivasi Belajar Siswa Interval Skor

$$
\begin{array}{ll}
(M+1,50 s)<X & A \\
(M+0,50 s)<X \leq(M+ & B \\
1,50 s) & \\
(M-0,50 s)<X \leq(M+0,50 s) & C \\
(M-1,50 s)<X \leq(M-0,50 s) & D \\
X \leq(M-1,50 s) & E
\end{array}
$$

(Azwar,2015)

Keterangan:

$\mathrm{X}=$ Total skor responden

$M=$ Mean ideal, $1 / 2$ (skor maksimal ideal+skor minimal ideal)

$s$ = Simpangan baku ideal, 1/6 (skor maksimal ideal-skor minimal ideal).

Data motivasi belajar siswa diolah tiap pertanyaan kemudian diolah berdasarkan indikator.Data perindikator setelah diolah maka motivasi belajar siswa dapat diketahui. Data motivasi belajar siswa dihitung dengan persamaan berikut:

$$
\%=\left(\frac{n}{N}\right) x 100 \%
$$

Keterangan:

$n=$ skor yang diperoleh

$N=$ jumlah seluruh skor maksimal

Analisis data gain dilakukan untuk melihat efek dari metode penggunaan media pembelajaran Kotak pop up. Hal ini dapat dilakukan dengan menggunakan persamaan uji gain berikut:

Keterangan:

$$
N-_{\text {gain }}=\frac{S_{\text {post }}-S_{\text {pre }}}{S_{\text {maks }}-S_{\text {pre }}}
$$

$N$-gain = gain ternormalisasi

$S_{\text {pre }}=$ skor awal (pree test)

$S_{\text {post }}=$ skor akhir (post test)

$\mathrm{S}_{\text {maks }}=$ skor maksimal

Hasil perhitungan diinterpretasikan dengan menggunakan gain ternormalisasi sebagai berikut

Tabel 3.5 kriteria NilaiN- Gain

Nilai gain standar

$\geq 0,7$

Keterangan

$0,7 \geq g \geq 0,3$

Tinggi

$\leq 0,3$

Sedang

Rendah

(Hake, 1998)

\section{Pembahasan \\ Metode Penelitian Tahap I}

Potensi dan Masalah 
Dari hasil dari kegiatan observasi yang dilakukan terhadap siswa kelas VIIIC SMPN 19 mataram menunjukan bahwa potensi yang ditemukan dalam penelitian ini adalah media pembelajaran sebagai pegangan siswa untuk belajar dirumah dan didalam kelas selama kegiatan pembelajaran dengan masalah yang paling utama adalah kurangnya motivasi belajar siswa kelas VIIIC SMPN 19 mataram mata pelajaran Fisika. Rendahnya motivasi belajar siswa ini ditunjukan dengan jarangnya siswa mengajukan pertanyaan, malasnya peserta didik mencatat materi pelajaran dan kurangnya respon terhadap pertanyaan yang disampaikan oleh guru. Salah satu penyebabnya adalah tidak adanya buku pegangan siswa untuk belajar di rumah dan siswa harus mencatat dan memfoto copy materi untuk proses belajar mengajar dikelas.

Berdasarkan potensi yang ditemukan ini, peneliti bermaksud mengembangkan media berupa kotak pop up. Kotak pop up pernah diterapkan disekolah lain tapi belum pernah dikembangkan di SMPN 19 mataram. Kotak pop up yang peneliti kembangkan memiliki keterkaitan sains dalam Al-Quran, pendidikan berkarakter, serta adanya evaluasi di masing-masing akhir materi.

Media pembelajaran kotak pop up yang akan dihasilkan yaitu terdiri dari cover depan kotak pop up, keterkaitan sains dalam Al-Quran, pendidikan berkarakter, standar kompetensi, kompetensi dasar, materi pembelajaran, contoh soal dan pembahasan serta evaluasi. Kotak pop up yang dibuat berbentuk kubus dan tulisan yang mudah dibaca. Desain awal produk dikerjakan dengan menggunakan kertas yang menyerupai tripleks kemudian dipotong segiempat sama besarnya sebanyak enam lembar dengan menggunakan kertas plasma untuk melapisi luar kotak dan untuk mengukur motivasi belajar siswa. Berbeda dengan penelitian yang telah dilakukan oleh Mahayani (2017), yang diukur adalah kelayakkan media, dan tidak memiliki variasi warna. Desain awal kotak pop up dapat dilihat pada lampiran 3 halaman 82 . Berbeda dengan penelitian yang telah dilakukan oleh Mahayani (2017).

Desain Awal Produk

Kondisi pada potensi dan masalah yang ada mendorong peneliti untuk mengembangkan kotak pop up untuk membantu proses belajar mengajar. Kotak pop up memiliki kelebihan antara lain dapat memotivasi siswa dalam proses pembelajaran. Selain itu juga kotak pop up ini memiliki warna yang bervariasi dan gambargambar menarik minat baca pada siswa.

Hasil Validasi Ahli

Media pembelajaran yang telah di desain divalidasi oleh ahli sebelum diuji pada kelompok kecil. Validasi kotak pop up dilakukan oleh 3 ahli 1 praktisi.

Hasil validasi dari ahli praktisi mengatakan tidak ada revisi terhadap produk karena sudah dikatakan layak untuk digunakan. Hasil yang berbeda diperoleh dari ahli I,II dan III merekomendasikan perbaikkan mengenai warna setiap cahaya pada materi,pada contoh soal serta kerapian. Hasil validasi ahli menunjukkan bahwa media pembelajaran kotak pop up layak digunakan dalam pembelajaran setelah melakukan revisi.

Revisi Produk

Revisi produk kotak pop up dilakukan pada pemberian warna pada gambar cahaya di materi dan menambahkan contoh soal dan kerapian pada kotak pop up nya.

\section{Metode Penelitian Tahap II}

Penggunaan media pembelajaran kotak pop up di SMPN 19 mataram untuk mneingkatkan motivasi belajar siswa pada mata pelajaran FISIKA materi cahaya dan alat optik. Sebelum menerapkan media pembelajaran kotak pop up, siswa mengisi angket motivasi belajar yang sebelumnya telah divalidasi. Angket yang telah diisi oleh siswa kemudian diolah untuk mengetahui besar motivasi siswa.

Motivasi belajar siswa diolah berdasarkan indikator masing-masing. Jumlah semua indikator adalah 5. Untuk indikator perhatian jumlahnya ada 1 dimana sebelum menggunakan $80 \%$ dan setelah penerapan meningkat menjadi $145 \%$. Kriteria peningkatan motivasi dikorelasikan dengan kriteria gain dimana diperoleh hasil peningkatan motivasi belajar siswa sebesar 0,68 dan berada pada kategori sedang. Aspek motivasi belajar yang kedua adalah relevansi dengan jumlah masingmasing 4 item sebelum dan sesudah dimana sebelum penerapan kotak pop up $43 \%$ dan setelah penerapan meningkat menjadi $84 \%$, dengan nilai gain sebenar 0,72 . Dan aspek motivasi belajar yang ketiga adalah kepercayaan diri dengan 9 item, sebelum penggunaan media besar motivasi siswa adalah $50 \%$ dan setelahnya menjadi $77 \%$ dengan nilai gain 0,53 untuk jumlah item soal 2 . Dan yang ke empat adalah kepuasan dengan banyak 2, sebelum menggunakan kotak pop up sebesar $53 \%$ dan setelah menggunakan menjadi $77 \%$ dengan nilai gain 0,50 .

Dalam pengukuran motivasi belajar siswa digunakan teknik analisis data berupa data kuantitatif, yang diperoleh peningkatan dengan menggunakan normalisasi gain (gain) untuk motivasi belajar berupa perhatian 0,68 dengan kriteria sedang, motivasi belajar relevansi 0,72 dengan kriteria sedang, motivasi belajar kepercayaan diri 0,53 dengan kriteria sedang, dan motivasi belajar kepuasan 0,50 dengan kriteria sedang. Peningkatan motivasi belajar secara klasikal juga berada pada kriteria sedang dengan 
normalisasi gain sebesar 0.5. Dengan demikian, hasil penelitian terhadap motivasi belajar siswa secara klasikal mengalami peningkatan motivasi belajar berada dalam kategori sedang.

\section{SIMPULAN DAN SARAN Simpulan}

Berdasarkan penelitian yang telah dilaksanakan dapat disimpulkan bahwa media pembelajaran berupa KOTAK POP UP dapat:

1. Teruji kevalidannya baik dari segi ahli media maupun materi, dimana untuk kriteria pendidikan semua ahli memberikan nilai $A$, untuk kriteria tampilan semua ahli memberikan nilai $A$, serta untuk kriteria teknis 2 ahli memberikan nilai $A$ dan 1 ahli memberikan nilai B maka dari itu media pembelajaran kotak pop up layak untuk digunakan.

2. Teruji keefektifannya karena mampu meningkatkan motivasi belajar siswa kelas VIII SMPN 19 Mataram pada materi cahaya dan alat optik. Dimana diperoleh gain untuk motivasi belajar berupa perhatian 0,68 dengan kriteria rendah, motivasi belajar berupa relevansi 0,72 dengan kriteria rendah, motivasi belajar berupa kepercayaan diri 0,53 dengan kriteria rendah dan yang terakhir motivasi belajar berupa kepuasan 0,50 dengan kriteria rendah. Sedangkan Peningkatan motivasi belajar secara klasikal juga berada pada kriteria sedang dengan Saran normalisasi gain sebesar 0,5.

Berdasarkan penelitiaan yang telah dilakukan, maka diberikan beberapa saran bagi peneliti selanjutnya yaitu:

1. KOTAK POP UP yang dikembangkan dapat digunakan dengan baik, namun masih memiliki kekurangan baik dari segi pendidikan, tampilan, dan kualitas teknis. Hal ini dapat dijadikan pertimbangan bagi peneliti selanjutnya untuk mengembangkan media pembelajaran yang lebih sempurna lagi.

2. KOTAK POP UP ini dapat dikembangkan untuk semua materi Fisika untuk materi yang berbeda.

3. Penelitian ini dilaksanakan sampai pada tahap uji coba kelompok kecil. Oleh karena itu diharapkan pada penelitian selanjutnya dilaksanakan sampai pada tahap penyebaran.

\section{DAFTAR RUJUKAN}

Arsyad, Azhar. 2014. Media Pembelajaran Edisi Revisi. Jakarta: Rajawali Pers

Arikunto,Suharsimin. 2010. Prosedur Penelitian. Jakarta: Rineka Cipta

Azwar, Saifuddin. 2015. Tes Prestasi. Yogyakarta: Pustaka Pelajar
Cahyo,Suryo,dkk. 2016. Ipa Fisika Jilid 2 Kurikulum 2013 .Jakarta: Erlangga

Giancoli.2001. Physics Fifth Edition.Jakarta: Erlangga

Hake, R.R. (1998). Interactive-engagement versustraditional methods: A six-thousandstudent survey of mechanics test data for introductory physics courses. American Journal of Physics 66, 64 (1998). 10.1119/ 1.18809

Hamalik, Oemar. 2001.Proses Belajar Mengajari. Jakarta: PT. Bumi Aksara

Mahayani, Septi. 2017. Pengembangan Media Pembelajaran Berupa Kotak Pop-up Berbasis Problem Solving Untuk Menunjang Pembelajaran Fisika Materi Cahaya dan Alat Optik: Institut Agama Islam Raden Intan Malang,Jurnal Pensisikan Fisika Diakses pada tanggal 08 Januari 2018

Riduwan. 2014. Metode dan Teknik Menyusun Proposal Penelitian. Bandung: Alfabeta

Sabaryati,Johri. 2016. Pengembangan Alat Peraga Sederhana Ayunan Magnetik Pada Materi Gaya Magnet Untuk Meningkatkan Motivasi Belajar Siswa.Universitas Muhammadiyah Mataram.Jurnal Pendidikan Fisika Vol.2 No.2,ISSN 2460-9587.

Sadirman. 2016. Interaksi\&Motivasi Belajar Mengajar. Jakarta: Rajawali Pers

Sugiyono.2016. Metode Penelitian Pendidikan, Pendekatan

Kuantitatif, Kualitatif,Dan

$R \& D$. Bandung:Alfabeta

Sugiyono. 2013. Metode Penelitian Kuantitatif Kualitatif dan $R \& D$. Bandung: Alfabeta

Sugiyanto, 2017. Pop-up sebagai media pembelajaran fisika materialat optik untuk $S M A$. Universitas Negeri Malang.jurnal fisika.Vol,6 No.2, ISSN 2252-6935.Diakses pada tanggal 04 maret 2018.

Uno, Hamzah B. 2014. Teori Motivasi \& Pengukurannya. Jakarta: PT. Bumi Aksara 